\title{
TARUGA (ANURA: RHACOPHORIDAE), A NEW GENUS OF FOAM-NESTING TREE FROGS ENDEMIC TO SRI LANKA
}

\author{
Madhava Meegaskumbura ${ }^{1,4,5}$, , Suyama Meegaskumbura ${ }^{1,5}$, Gayan Bowatte ${ }^{1}$, Kelum Manamendra- \\ Arachchi $^{2}$, Rohan Pethiyagoda ${ }^{3}$, James Hanken ${ }^{4}$ and Christopher J. Schneider ${ }^{5}$ \\ ${ }^{1}$ Department of Zoology, Faculty of Science, University of Peradeniya, Sri Lanka \\ ${ }^{2}$ Postgraduate Institute of Archaeology, 407 Bauddhaloka Mawatha, Colombo 07, Sri Lanka \\ ${ }^{3}$ Ichthyology Section, Australian Museum, 6 College Street, Sydney, NSW 2000, Australia \\ ${ }^{4}$ Museum of Comparative Zoology, Harvard University, 24 Oxford Street, Cambridge MA 02138, USA \\ ${ }^{5}$ Department of Biology, Boston University, 5 Cummington Street, Boston MA 02215, USA
}

Accepted 08 December 2010

\begin{abstract}
Phylogenetic relationships among foam-nesting clades of Old World tree frogs are analyzed using both nuclear and mitochondrial DNA data, with particular focus on Sri Lankan members of the genus Polypedates. A distinctive, highly supported endemic Sri Lankan clade is identified, and recognized as a new genus, Taruga. This clade, which had previously been assigned to the genus Polypedates, includes $P$. eques, $P$. fastigo and $P$. longinasus. A combination of characters distinguishes adult Taruga from Polypedates: Taruga possess a dorsolateral glandular fold that extends from the posterior margin of the upper eyelid to the mid-flank (vs. a supratympanic fold that curves over the dorsal margin of the tympanic membrane in Polypedates); a prominent calcar at the distal end of the tibia (absent in most Polypedates); a more acutely pointed snout; and 6-10 prominent conical tubercles surrounding the cloaca (absent in Polypedates). Tadpoles of Taruga eques and Polypedates cruciger are distinguished by several characters, including features of the buccal cavity and the form of the vent tube. Taruga is the sister group of the remaining Polypedates sensu stricto.
\end{abstract}

Key words: Polypedates, Rhacophorinae, systematics, tadpole morphology, molecular phylogenetics

\section{INTRODUCTION}

Foam nesting is a reproductive mode that occurs in many species of anuran amphibians. Typically, eggs are laid in a foamy mass that overhangs a pool of water, into which late-stage tadpoles fall and undergo further development. Foam nesting occurs in several phylogenetically disparate frog lineages, including Leptodactylidae, Hyperoliidae, Leiuperidae, Myobatrachidae and Rhacophoridae (Wells, 2007). Within each lineage, entire clades, genera or single species (as in Hyperoliidae) practice foam nesting (Duellman and Trueb, 1986; AmphibiaWeb, 2011).

The Rhacophoridae, a well-supported monophyletic group (Frost et al., 2006), contains three well recognized foam-nesting genera: Rhacophorus, Polypedates and Chiromantis (Chirixalus) (Meegaskumbura et al., 2002; Wilkinson and Drewes, 2000). Whereas each genus in turn constitutes a distinct, monophyletic group (Richards and Moore, 1998;
Meegaskumbura et al., 2002; Wilkinson et al., 2002; Frost et al., 2006), phylogenetic relationships amongst these genera are not yet fully resolved (Meegaskumbura, 2007).

Five foam-nesting species of anurans from Sri Lanka have previously been assigned to the genus Polypedates: P. maculatus, $P$. cruciger, $P$. eques, $P$. fastigo, and $P$. longinasus (Meegaskumbura et al., 2002; ManamendraArachchi and Pethiyagoda, 2005). Four of these species are endemic to the island, whereas $P$. maculatus also occurs on the Indian Subcontinent. Sri Lankan Polypedates, however, possess two different body forms, both as adults and as tadpoles. Moreover, each body form displays a distinct pattern of distribution: slender-bodied, sharp-snouted species with small ranges ( $P$. eques, $P$. fastigo and $P$. longinasus; Figs. 1, 2, 3A and 4B); and stouter, bluntsnouted species with wider distributions $(P$. cruciger and P. maculatus, Figs. 3B and 3A), respectively. The tadpoles of these two groups, too, are distinctive (Fig. 4).

\footnotetext{
*Corresponding author's email: madhava_m@mac.com
} 


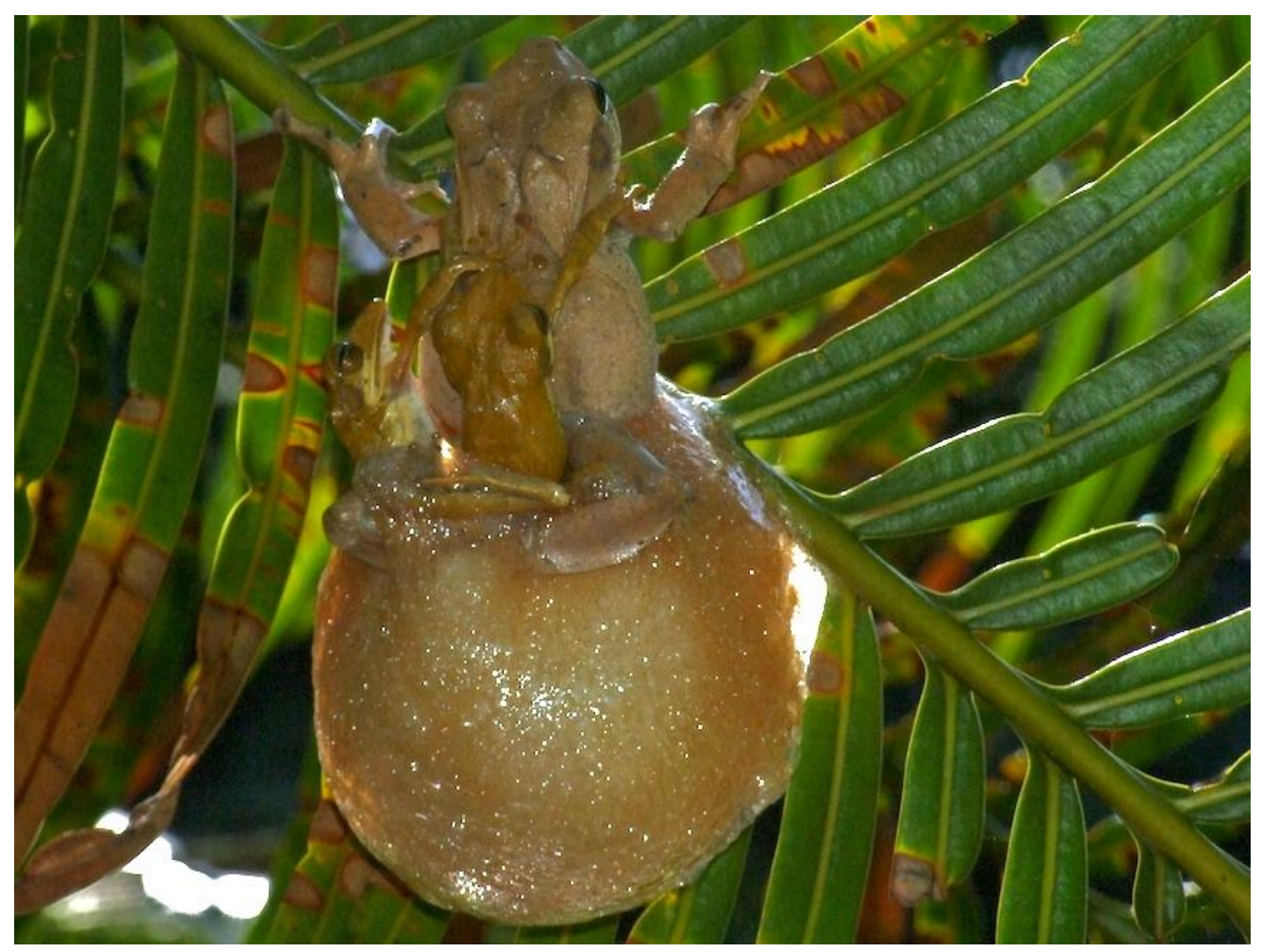

Figure 1. A foam nest being made by Polypedates cruciger. Several males may be involved in fertilizing the eggs. The female deposits her eggs in a foamy mass overhanging water. The eggs undergo development within the foam nest for 5-6 days; tadpoles of Gosner stage 23 fall into water to undergo further development.

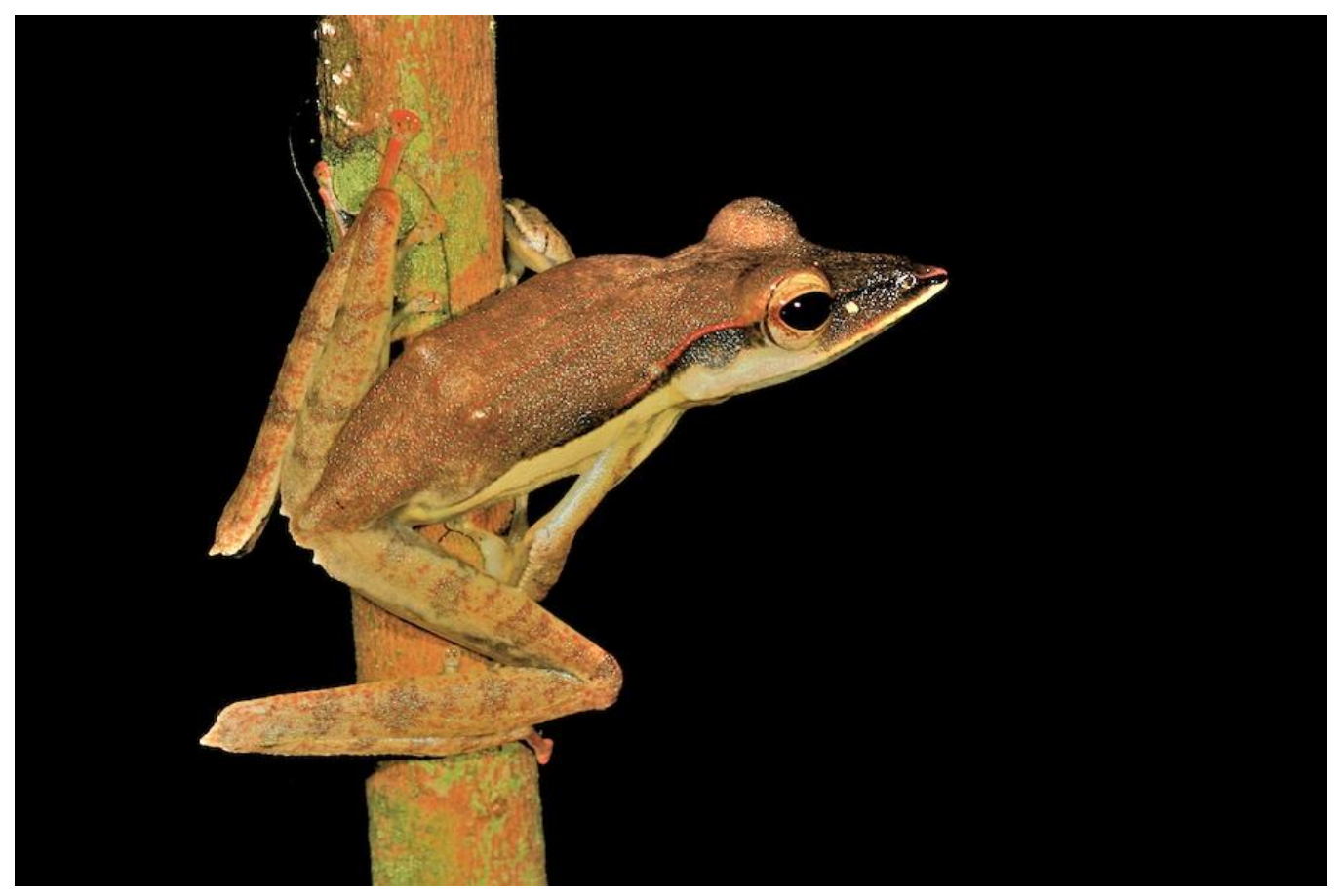

Figure 2. Taruga fastigo. Note the prominent calcar on the tibia, tubercles around vent (two of these visible in this photo), and a glandular fold extending from the back of the eye to the mid-flank region. This male was photographed in the type locality for the species, at Morningside Estate, Eastern Sinharaja (1060 $\mathrm{m}$ asl). 


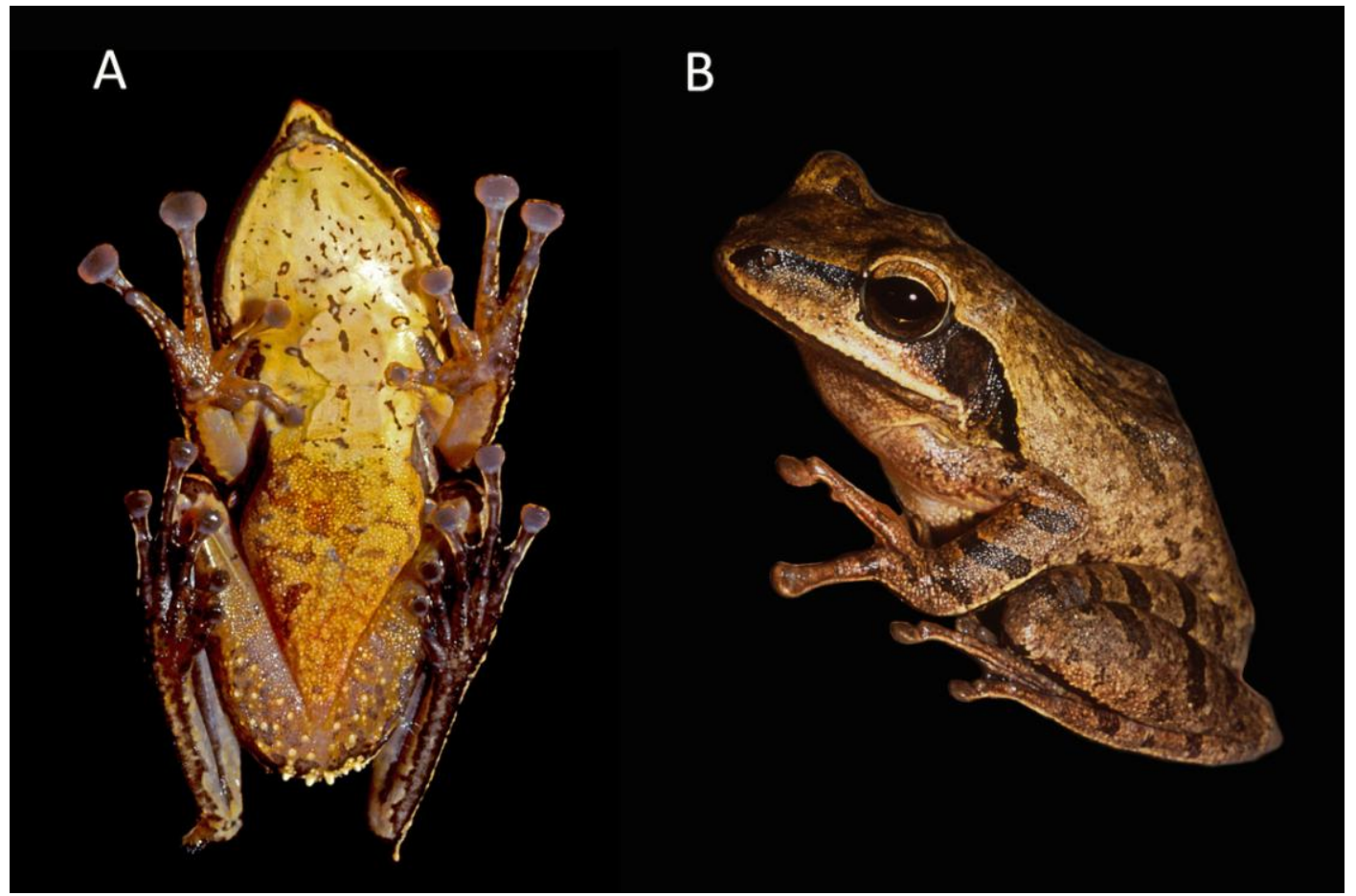

Figure 3. (A) Taruga longinasus, ventral aspect, showing the papillae in the region of the cloaca, calcar on tibia and the pointed snout. (B) Polypedates maculatus, showing the rounded snout, supratympanic membrane that curves around tympanum and ends anterior to the mid-flank.

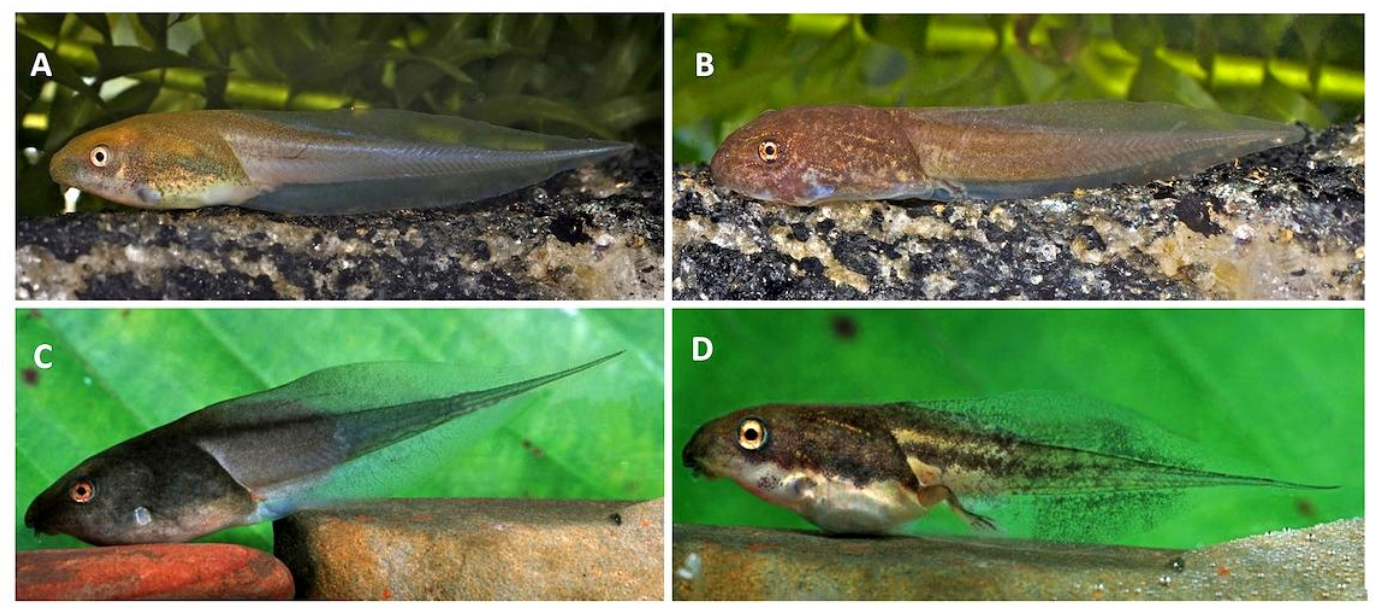

Figure 4. Tadpoles of Gosner stage 32-37 (A) Polypedates cruciger, (B) Taruga eques, (C) P. otilophus and (D) P. leucomystax. Tadpoles of Taruga eques differ from all others in having an acute tail fin tip, position of eye, distinct body shape, and having a pronounced extension of the connective tissue covering the proximal tail musculature about one-third along the length of the tail. (Photographs (C) and (D) courtesy of Alexander Haas).

Here we evaluate the genus-level relationships among these frogs through a phylogenetic analysis that uses both mitochondrial and nuclear DNA markers and includes representatives of all known foamnesting genera within Rhacophoridae. Our analysis reveals a hitherto unrecognized lineage of foam-nesting tree frogs endemic to Sri Lanka, which we recognize as a new genus. We also describe the morphological characters that distinguish adults and tadpoles of this genus from those of Polypedates. 
Table 1. Taxonomic information, collection reference numbers, country, gene fragments for which sequences are not available (X) and Genbank reference numbers of the species included in this study. (FMNH - Field Museum of Natural History Chicago; ZRC - Zoological Reference Collection, Singapore; WHT - Wildlife Heritage Trust, Sri Lanka; MVZ - Museum of Vertebrate Zoology, University of California Berkeley; MCZ - Museum of Comparative Zoology, Harvard University)

\begin{tabular}{|c|c|c|c|c|c|c|c|c|c|}
\hline \multirow[t]{2}{*}{ Genus } & \multirow[t]{2}{*}{ Species } & \multirow[t]{2}{*}{ Reference number } & \multirow[t]{2}{*}{ Country } & \multicolumn{6}{|c|}{ Gene fragments and Genbank reference numbers } \\
\hline & & & & $12 \mathrm{~s}$ & $16 \mathrm{~s}$ & cyt- $b$ & Rag-1 & BDNF & Rhod \\
\hline \multirow[t]{12}{*}{ Polypedates } & cruciger & WHT 2640 & Sri Lanka & $\mathrm{X}$ & GQ204687 & GQ204504 & GQ204570 & GQ204446 & GQ204632 \\
\hline & cruciger & WHT Kuru3 & Sri Lanka & GQ204746 & GQ204692 & GQ204508 & $\mathrm{X}$ & $\mathrm{X}$ & $\mathrm{X}$ \\
\hline & maculatus & WHT Kuru2 & Sri Lanka & GQ204747 & $\mathrm{X}$ & GQ204510 & GQ204575 & GQ204451 & $\mathrm{X}$ \\
\hline & maculatus & WHT Kantalai & Sri Lanka & $\mathrm{X}$ & GQ204694 & GQ204511 & GQ204576 & GQ204451 & GQ204637 \\
\hline & leucomystax & ZRC 1.15269 & Java & $\mathrm{X}$ & GQ204693 & GQ204509 & GQ204574 & GQ204450 & GQ204636 \\
\hline & colletti & FMNH 242765 & Malaysia & GQ204750 & GQ204697 & GQ204514 & GQ204579 & GQ204454 & X \\
\hline & macrotis & FMNH 239119 & Malaysia & GQ204748 & GQ204695 & GQ204512 & GQ204577 & GQ204452 & GQ204638 \\
\hline & otilophus & FMNH 239147 & Malaysia & GQ204749 & GQ204696 & GQ204513 & GQ204578 & GQ204453 & GQ204639 \\
\hline & leucomystax var. A & FMNH 253086 & Vietnam & GQ204752 & GQ204699 & GQ204516 & GQ204581 & GQ204456 & $X$ \\
\hline & leucomystax var. B & FMNH 253029 & Vietnam & GQ204751 & GQ204698 & GQ204515 & GQ204580 & GQ204455 & $X$ \\
\hline & leucomystax & FMNH 255296 & Laos & GQ204753 & GQ204700 & GQ204517 & GQ204582 & GQ204457 & $\mathrm{X}$ \\
\hline & leucomystax & FMNH 256451 & Laos & GQ204754 & GQ204701 & GQ204518 & GQ204583 & $\mathrm{X}$ & $\mathrm{X}$ \\
\hline \multirow[t]{4}{*}{ Taruga } & eques & WHT 2741 & Sri Lanka & $\mathrm{X}$ & GQ204689 & GQ204505 & GQ204571 & GQ204447 & GQ204633 \\
\hline & eques & WHT 2714 & Sri Lanka & $X$ & GQ204688 & $\mathrm{X}$ & $\mathrm{X}$ & $\mathrm{X}$ & $\mathrm{X}$ \\
\hline & fastigo & WHT 2783 & Sri Lanka & $\mathrm{X}$ & GQ204690 & GQ204506 & GQ204572 & GQ204448 & GQ204634 \\
\hline & longinasus & WHT KAN1 & Sri Lanka & GQ204745 & GQ204691 & GQ204507 & GQ204573 & GQ204449 & GQ204635 \\
\hline \multirow[t]{5}{*}{ Rhacophorus } & anamensis & FMNH 253934 & Vietnam & GQ204768 & GQ204717 & GQ204534 & GQ204598 & GQ204470 & GQ204653 \\
\hline & bipunctatus & FMNH 253114 & Vietnam & GQ204767 & GQ204716 & GQ204533 & $\mathrm{X}$ & GQ204469 & GQ204652 \\
\hline & calcaneus & FMNH 256465 & Lao & GQ204770 & GQ204719 & GQ204536 & GQ204600 & $\mathrm{X}$ & GQ204655 \\
\hline & chenfui & FMNH 232964 & China & GQ204763 & GQ204712 & GQ204529 & GQ204594 & GQ204467 & GQ204648 \\
\hline & dulitensis & FMNH 235741 & Malaysia & GQ204766 & GQ204715 & GQ204532 & GQ204597 & $\mathrm{X}$ & GQ204651 \\
\hline
\end{tabular}




$\begin{array}{lllllllll}\text { gauni } & \text { FMNH 235047 } & \text { Malaysia } & \text { GQ204765 } & \text { GQ204714 } & \text { GQ204531 } & \text { GQ204596 } & \text { X } & \text { GQ204650 } \\ \begin{array}{l}\text { nigropalmatus } \\ \text { pardalis }\end{array} & \text { FMNH 230902 } & \text { Malaysia } & \text { GQ204761 } & \text { GQ204710 } & \text { GQ204527 } & \text { GQ204592 } & \text { GQ204465 } & \text { GQ204646 } \\ & \text { FMNH 231366 } & \text { Malaysia } & \text { GQ204762 } & \text { GQ204711 } & \text { GQ204528 } & \text { GQ204593 } & \text { GQ204466 } & \text { GQ204647 } \\ \text { reinwardtii } & \text { ZRC 1.1.5273 } & \text { Java } & \text { GQ204771 } & \text { GQ204720 } & \text { GQ204537 } & \text { GQ204601 } & \text { GQ204472 } & \text { GQ204656 } \\ \text { reinwardtii } & \text { FMNH 235034 } & \text { Malaysia } & \text { GQ204764 } & \text { GQ204713 } & \text { GQ204530 } & \text { GQ204595 } & \text { GQ204468 } & \text { GQ204649 } \\ \text { Fp } & \text { FMNH 255280 } & \text { Gas } & \text { GQ204769 } & \text { GQ204718 } & \text { GQ204535 } & \text { GQ204599 } & \text { GQ204471 }\end{array}$

sp.

FMN

Laos

GQ204769

GQ204718

GQ204535 GQ204599

GQ204471

GQ204654

\begin{tabular}{|c|c|c|c|c|c|c|c|c|c|}
\hline \multirow{3}{*}{$\begin{array}{l}\text { Chiromantis } \\
\text { (Chirixalus) }\end{array}$} & doriae & FMNH 255215 & Laos & GQ204772 & GQ204721 & GQ204538 & GQ204602 & GQ204473 & GQ204657 \\
\hline & nongkhorensis & FMNH 255378 & Laos & GQ204774 & GQ204723 & GQ204540 & GQ204604 & GQ204475 & GQ204659 \\
\hline & vittatus & FMNH 255217 & Laos & GQ204773 & GQ204722 & GQ204539 & GQ204603 & GQ204474 & GQ204658 \\
\hline \multirow[t]{3}{*}{ Chiromantis } & rufescens & CAS & Africa & GQ204775 & GQ204724 & GQ204541 & GQ204605 & GQ204476 & GQ204660 \\
\hline & xerampelina & MVZ 234606 & Africa & GQ204785 & GQ204734 & GQ204551 & $\mathrm{X}$ & $\mathrm{X}$ & $\mathrm{X}$ \\
\hline & petersi & MVZ 234168 & Africa & GQ204784 & GQ204733 & GQ204550 & $\mathrm{X}$ & $\mathrm{X}$ & $\mathrm{X}$ \\
\hline Theloderma & asperum & ZRC 1.1.9321 & Malaysia & GQ204776 & GQ204725 & GQ204542 & GQ204606 & $\mathrm{X}$ & GQ204661 \\
\hline \multirow[t]{2}{*}{ Nyctixalus } & pictus & FMNH 231094 & Malaysia & GQ204777 & GQ204726 & GQ204543 & GQ204607 & GQ204477 & $\mathrm{X}$ \\
\hline & pictus & MVZ 239460 & Indonesia & GQ204783 & GQ204732 & GQ204549 & GQ204613 & GQ204483 & GQ204666 \\
\hline \multirow[t]{2}{*}{ Buergeria } & oxycephalus & MVZ 230425 & China & GQ204781 & GQ204730 & GQ204547 & GQ204611 & GQ204481 & GQ204665 \\
\hline & oxycephalus & MVZ 230426 & China & GQ204782 & GQ204731 & GQ204548 & GQ204612 & GQ204482 & $X$ \\
\hline
\end{tabular}




\section{MATERIALS AND METHODS}

\section{Tissue extraction, PCR amplification and DNA sequencing}

We obtained DNA sequence data from 40 individuals of 31 putative rhacophorid species, which represent all currently recognized genera of foam-nesting species within Rhacophoridae as well as several basal rhacophorid outgroup species (Table 1). Tissues of Sri Lankan species ( 8 individuals, 5 species) were collected in the field; the rest (32) were obtained from naturalhistory museum collections.

DNA was extracted from ethanol-preserved tissues using Qiagen tissue-extraction kits following manufacturers' protocols. A total of 3730 base pairs (bp) were sequenced, including three mitochondrial gene fragments with a total of $\sim 1500 \mathrm{bp}$ and three nuclear gene fragments with a total of $\sim 2230 \mathrm{bp}$. Portions of the mitochondrial $12 \mathrm{~S}$ and $16 \mathrm{~S}$ ribosomal RNA (12S and $16 \mathrm{~S}$, respectively) and cytochrome $b$ (cyt- $b$ ) genes were amplified by PCR and sequenced directly using dye-termination cycle sequencing. The following primer sets were used for both PCR and sequencing of mitochondrial genes: $12 \mathrm{Sa}$ and 12Sb (Palumbi, 1996), which amplified $\mathrm{a} \sim 380 \mathrm{bp}$ fragment of the 12S rRNA gene; 16Sar and 16Sbr (Palumbi, 1996), which amplified $\sim 550 \mathrm{bp}$ of the 16S rRNA gene; and CBJ10933 and BSF4 (Bossuyt and Milinkovitch, 2000), which amplified a 567 bp region of the $c y t-b$ gene. PCR conditions for amplification of all three fragments were as follows: denaturation at $95^{\circ} \mathrm{C}$ for $40 \mathrm{~s}$, annealing at $45^{\circ} \mathrm{C}$ for $40 \mathrm{~s}$, and extension at $72^{\circ} \mathrm{C}$ for $50 \mathrm{~s}, 35$ cycles, with a final extension of $72^{\circ} \mathrm{C}$ for $5 \mathrm{~min}$.

Nuclear Rag-1 (recombination activating gene-1), BDNF (brain-derived neurotrophic factor) and Rhod (rhodopsin exon-1) partial gene fragments were amplified by PCR. Two sets of primers were used to amplify two fragments of the Rag-1 gene for a total sequence length of 1403 bp: Amp-Rag1F (5'-AGC TGC AGY CAR TAC CAY AAR ATG TA - 3') and AmpRag1R1 (5'-AAC TCA GCT GCA TTK CCA ATR TCA CA-3'); and Amp-Rag1F1 (5'-ACA GGA TAT GAT GAR AAG CCT GT-3') and Amp-Rag1R (5'-TTR GAT GTG TAG AGC CAG TGG TGY TT-3') (Mauro et al., 2004). Primers BDNFF $\left(5^{\prime}-\mathrm{CAT}\right.$ CCT TTT CCT TAC TAT GGT T-3') and BDNFR (5'-TTC CAG TGC CTT TTG TCT ATG-3') (Murphy et al., 2001), were used to amplify $550 \mathrm{bp}$ of the BDNF gene; and Rhod.ma (5'-AAC GGA ACA
GAA GGY CC-3') and Rhod.md (5'-GTA GCG AAG AAR CCT TC-3') (Hoegg et al., 2004), were used to amplify 281 bp of Rhodopsin exon. PCR conditions for amplification of Rag-1 were denaturation at $95^{\circ}$ $\mathrm{C}$ for $45 \mathrm{~s}$, annealing at $52-58^{\circ} \mathrm{C}$ for $45 \mathrm{~s}$, and extension at $72^{\circ} \mathrm{C}$ for $60 \mathrm{~s}, 35-38$ cycles, with a final extension at $72^{\circ} \mathrm{C}$ for $10 \mathrm{~min}$. PCR parameters for amplification of BDNF and rhodopsin gene fragments were the same as for Rag-1 amplification except for the annealing temperatures, which were $50^{\circ} \mathrm{C}$ and $45^{\circ} \mathrm{C}$, respectively. All products were gel purified and sequenced on an ABI 3100 automated sequencer following manufacturers' protocols.

\section{Alignment of sequences and phylogenetic analyses}

Chromatograms were edited using Codon Code Aligner (v. 1.5.2). The program Se-Al (v. 2.0a: Rambaut, 1996) was used to align the coding regions of cyt- $b$, Rhodopsin, BDNF and Rag-1 using translated amino acid sequences. The $12 \mathrm{~S}$ and 16S rRNA gene sequences were aligned visually. Positions that were difficult to align, and in which we had low confidence in positional homology, were excluded from the phylogenetic analyses.

The Partition Homogeneity Test as implemented in PAUP* (v. 4.0b10) was used to assess the congruence of the six gene fragments. All available species (40 taxa) were included in a single dataset. A non-partitioned Bayesian analysis, and an equal-weights unordered Maximum Parsimony Analysis were performed.

Modeltest 3.06 (Posada and Crandall, 1998) was used to choose the model of nucleotide substitution that best fit the datasets. The General Time Reversible model with invariant sites and gamma distribution (GTR+I+G) yielded the best-fit for all datasets (using the Akaike information criterion: Akaike, 1974). This was implemented as a non-partitioned Bayesian analysis, with all parameters estimated during the run.

The tree was rooted using Buergeria oxycephalus (China), Theloderma asperum (Malaysia) and Nyctixalus pictus (Malaysia and Indonesia). Previous studies suggest that these taxa represent the basal clades of Rhacophoridae and hence can be justified as outgroups to root the tree of the foam-nesting species (Meegaskumbura et al. 2002; Bossuyt et al., 2006; Frost et al., 2006; Meegaskumbura, 2007). 
Bayesian inference as implemented in MrBayes (v. 3.1: Huelsenbeck and Ronquist, 2001) was used to generate a phylogenetic hypothesis of relationships among the taxa with the parameters of a general time-reversible model of sequence evolution with gammadistributed rate variation among sites and a proportion of invariant sites $(\mathrm{GTR}+\mathrm{I}+\mathrm{G})$ estimated during the run. Four MetropolisCoupled Markov Chain Monte Carlo (MCMCMC) chains were run for one million generations and the summed likelihood of the four chains converged on a stationary value by 250,000 generations (burn-in time). Burn-in time was determined using the program AWTY (Wilgenbusch et al., 2004). The frequency of clades in trees that were sampled every ten generations from the last 250,000 generations (a total of 25,000 trees) was used as an estimate of the posterior probabilities of those clades (Huelsenbeck et al., 2001). Uniform priors were specified, and branch lengths, topology and nucleotide substitution parameters were unconstrained. For the Maximum likelihood analysis, we used the GTR+I+G model of nucleotide substitution with the parameters estimated from the Bayesian analysis. A single heuristic search with Tree Bisection and Reconnection (TBR) branch swapping was conducted using PAUP*4.0b10 (Swofford, 2002). Tree searches under a Maximum Parsimony criterion used heuristic searches with TBR branch-swapping and 100 replicates with random taxon addition as implemented in PAUP*4.0b10. A bootstrap analysis (100 replicates, random stepwise addition with 100 reps) to determine node support was also carried out within a maximum parsimony framework.

\section{Adult morphology}

The distinguishing external morphological features of all Polypedates species in Sri Lanka were evaluated. Characters used by Manamendra-Arachchi and Pethiyagoda (2005) were noted for all individuals. The following characters were measured to the nearest $0.1 \mathrm{~mm}$ using vernier calipers: eye diameter (ED); eyeto-nostril distance (EN); eye-to-snout length (ES); distal end of tibia length (FEL); length of third finger (FLIII); pes length (FOL); head length (HL); head width (HW); internarial distance (IN); interorbital distance (IO); nostrilto-snout length (NS); snout-vent length (SVL); tibia length (TBL); and length of fourth toe (TLIV).
X-ray computed tomography (CT) scans of skulls of Taruga eques (BMNH 1947.2.27.56), $P$. cruciger (BMNH 1875.2.27.8) and $P$. leucomystax (MCZ A-135392) were prepared by the Digimorph imaging facility at University of Texas Austin (BMNH: Natural History Museum, London; MCZ: Museum of Comparative Zoology, Harvard University.). All material examined are listed in Appendix 1.

\section{Tadpole morphology}

Tadpoles of Taruga eques were collected from a pond in a tea estate at Agarapatana (1550 m elevation) and $P$. cruciger from a man-made pond at the University of Peradeniya. They were fixed in $10 \%$ neutral-buffered formalin (NBF) and preserved in a 1:1 mixture of $70 \%$ ethanol and $10 \% \mathrm{NBF}$. Measurements were made to the nearest $\pm 0.01 \mathrm{~mm}$ using a digital caliper and a graduated microscope attachment (Motic K-400) fitted with a drawing tube. Terminology used to describe external features follows McDiarmid and Altig (2000); terminology for internal oral features follows Wassersug (1976). Only Gosner (1960) stage-38 tadpoles were evaluated.

\section{RESULTS}

\section{Molecular phylogenetics and systematics}

The complete dataset initially consisted of DNA sequences of $3730 \mathrm{bp}$ length. A total of 3404 bp remained after removing regions of the mitochondrial $12 \mathrm{~S}$ and $16 \mathrm{~S}$ rRNA genes for which alignment was ambiguous and confidence of positional homology was low, but retaining all positions of the cyt- $b$ and nuclear genes. The Partition Homogeneity test showed that the data are congruent $(\mathrm{p}>0.01)$ and that the combined analysis of data is justified. Model test results show that $\mathrm{GTR}+\mathrm{I}+\mathrm{G}$ is the best fit (based on AIC) of the 56 models considered for the dataset.

We chose as our best tree the one with the highest likelihood from the unpartitioned Bayesian analysis. All nodes are well supported, with high posterior probabilities (> 95\%; Fig. 5). Maximum parsimony analysis yields two equally parsimonious trees (tree length 4161) and these trees agreed in major clade arrangement to a great degree with the clade arrangement of the Bayesian tree (the two maximum parsimony trees are not shown). 


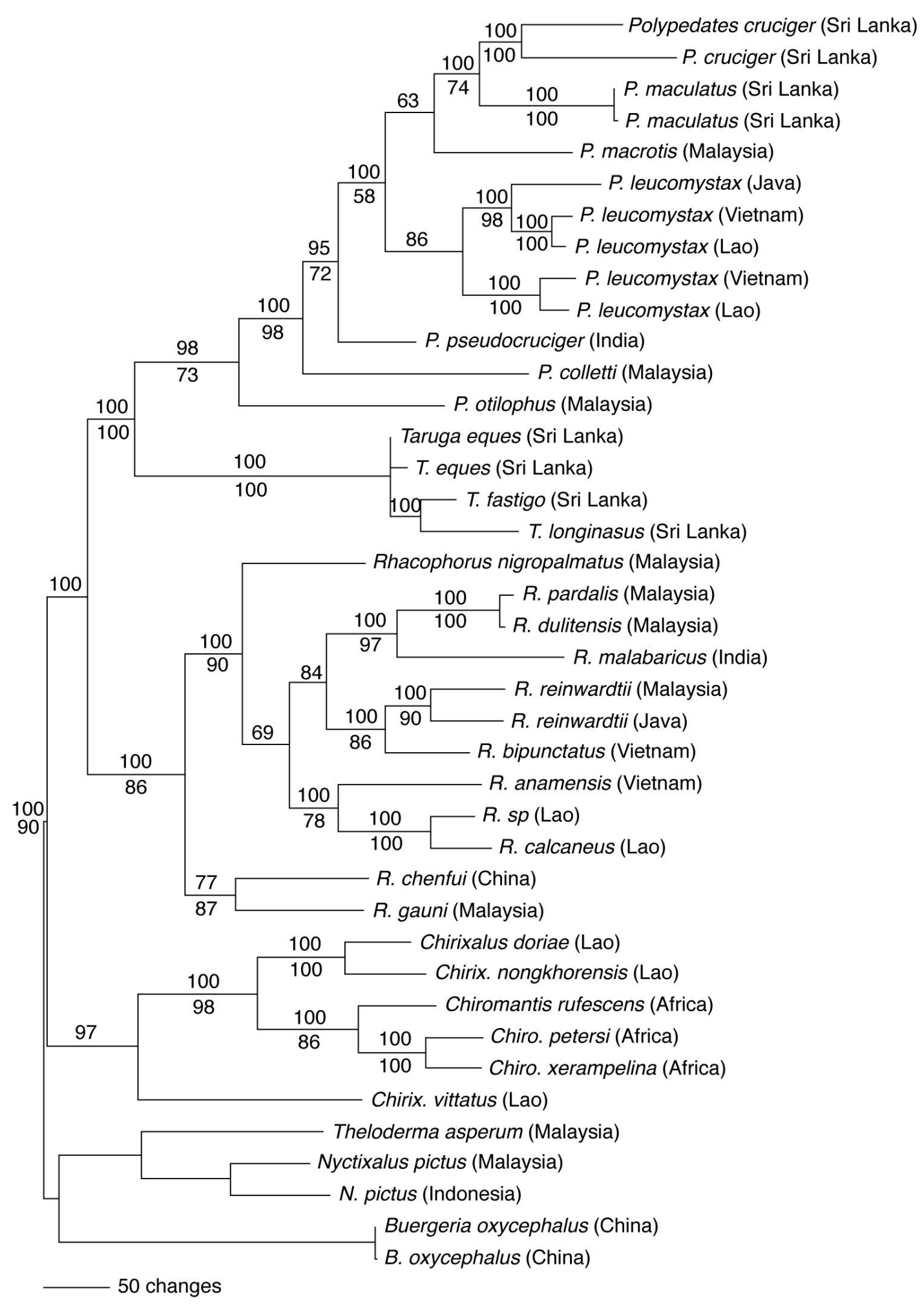

Figure 5. Bayesian phylogram with posterior probabilities shown above nodes, parsimony bootstrap values shown below nodes. All the major nodes that distinguish foam nesting rhacophorid genera have high support; Taruga, new genus, is a highly supported and is the basal sister taxon to Polypedates. 
Major phylogenetic conclusions, all of which receive high clade support in the Bayesian tree (Fig. 5) and the parsimony trees, are: (1) all Sri Lankan species of Polypedates are contained within two distinct clades: a basal, endemic Sri Lankan clade, which includes $P$. eques, $P$. fastigo and $P$. longinasus; and a clade which contains two widely-distributed species, $P$. cruciger and $P$. maculatus, and which is nested within Southeast Asian and Indian taxa; (2) the genus Rhacophorus and the endemic Sri Lankan clade are reciprocally monophyletic; and (3) Chiromantis is nested within the Chirixalus group.

\section{Taruga, new genus}

Type species:

Polypedates fastigo Manamendra-Arachchi and Pethiyagoda, 2001. Type series (including the Holotype WHT2352) is deposited in the National Museum of Sri Lanka.

Included species:

Polypedates eques Günther, 1858

Rhacophorus longinasus Ahl, 1927

Etymology. Taruga in Sanskrit and early Sinhala refers to "tree climber," a reference to the arboreal habitat of these frogs. Gender masculine.

Diagnosis. Several adult characters and character states distinguish Taruga from Sri Lankan Polypedates (Figs. 2, 3A and 6; Figs. 1 and 3B). Taruga have a straight or slightly curved dorsolateral glandular fold that extends from the back of the upper eyelid to the midflank, whereas Polypedates have a supratympanic fold that curves around the dorsal margin of the tympanum. Additionally, Taruga possess a prominent calcar at the distal end of the tibia (absent in most Polypedates); 6-10 prominent conical tubercles around the cloaca (absent in Polypedates); and a pointed snout in both dorsal and lateral aspects (vs. a shorter, more rounded snout in Polypedates) (Fig. 6). Snout acuteness differs markedly between the two genera; snout angle in Taruga varies between $58^{\circ}$ and $70^{\circ}$ (T. longinasus, 58 $; T$. eques, $70^{\circ} ;$ T. fastigo, $67^{\circ}$ ) whereas in Sri Lankan Polypedates it varies between $76^{\circ}$ and $92^{\circ}\left(P\right.$. cruciger, 77 to $92^{\circ} ; P$. maculatus, $76^{\circ}$ ): data from Manamendra-Arachchi and Pethiyagoda (2005).

The cranium of $T$. eques differs from that of $P$. cruciger and $P$. leucomystax in several respects (Fig. 7). The skull of T. eques is narrow and long in dorsal view; skull length/width ratio 0.90 , frontoparietal length/width ratio 1.57 (the skull is wide and short in $P$. cruciger and $P$. leucomystax; skull length/width 1.03 and 1.12, frontoparietal length/width 1.40 and 1.25 in the two genera, respectively). The dorsal surface of the cranium is smooth in Taruga (with bony ridges in $P$. cruciger and $P$. leucomystax). The other features by which the two genera differ are: posterior margin of frontoparietal blunt in Taruga (with two pointed bony ridges in $P$. cruciger, concave in $P$. leucomystax); the anterior margin of the frontoparietal is convex in Taruga (concave in $P$. cruciger, straight in $P$. leucomystax); pterygoid strongly curved in Taruga (slightly curved in $P$. cruciger and $P$. leucomystax); and orbit dorsally long and narrow, length/width ratio 2.1 in Taruga (short and wide, length/width equals 1.6 in $P$. cruciger, 1.8 in P. leucomystax).

Tadpoles of $T$. eques and $P$. cruciger differ markedly in external morphology (Table 2; Figs. 4 and 8). Taruga eques has a pointed snout in dorsal view (rounded in $P$. cruciger), dorsallydirected eyes (laterally directed in $P$. cruciger) and a thin dorsal lip and groove at the base of the tail (absent in $P$. cruciger). It also lacks a marked, whip-like flagellum at the tip of the tail (present in P. cruciger).

In lateral view (Figs. 4 and 8), tadpoles of $T$. eques feature a sinistral spiracle attached to the trunk along most of its length, its inner wall free and formed such that the aperture opens laterally instead of posteriorly (a sinistral and cylindrical spiracle, centripetal, its distal end is directed posteriorly); the ventral tail fin originates at the caudal end of the trunk (originates from the trunk's ventral surface in $P$. cruciger); the dorsal fin originates at the caudal end of the trunk (originates from the trunk's dorsal surface in $P$. cruciger); and the vent opens as a dextral aperture between the hind limb and tail and does not form a tube (a distinct conical dextral vent tube, open at the free end, originates between the hind limb and the tail in P. cruciger; Fig. 9). The configuration of the vent in Taruga is a derived and possibly unique character-state in anuran larvae, which typically possess a vent tube (McDiarmid and Altig, 2000).

The larval buccal cavity also differs in the two species (Table 3 and Fig. 10). Characteristic features of the buccal floor in Taruga eques are; heart-shaped prelingual arena (U-shaped in $P$. cruciger); absence of prelingual-arena papillae 
(one pair in $P$. cruciger); three major digitations of the anterior prelingual arena palps (two in $P$. cruciger); flat and broad, multifurcated, posteriorly-directed posterior prelingual arena palps (long and medially directed with projections in $P$. cruciger); absence of papillae on the anterior wall of the buccal cavity (4-5 pairs in $P$. cruciger); tongue rounded (slightly conical in $P$. cruciger); a single pair of lingual papillae (two unequally-sized pairs in $P$. cruciger); lingual pigmentation present (absent in $P$. cruciger); tongue attached posteriorly with indiscernible buccal floor musculature, lacking a notch (tongue fully attached to prominent musculature, in a notch, in $P$. cruciger); a U- shaped, depressed buccal floor arena (BFA; triangular and elevated in $P$. cruciger); fewer than 50 BFA pustulations (more than 50 in $P$. cruciger); and 19-21 BFA papillae (11-13 in $P$. cruciger).

Characteristic features of the buccal roof in Taruga (Table 3 and Fig. 10) are; broad, Vshaped prenarial arena (U-shaped in $P$. cruciger); a broad, V-shaped anterior transverse ridge (crescentic in $P$. cruciger); absence of an anterior projection on the narial papilla (present in $P$. cruciger); and five pairs of arena papillae (four pairs in P. cruciger).

\section{A}

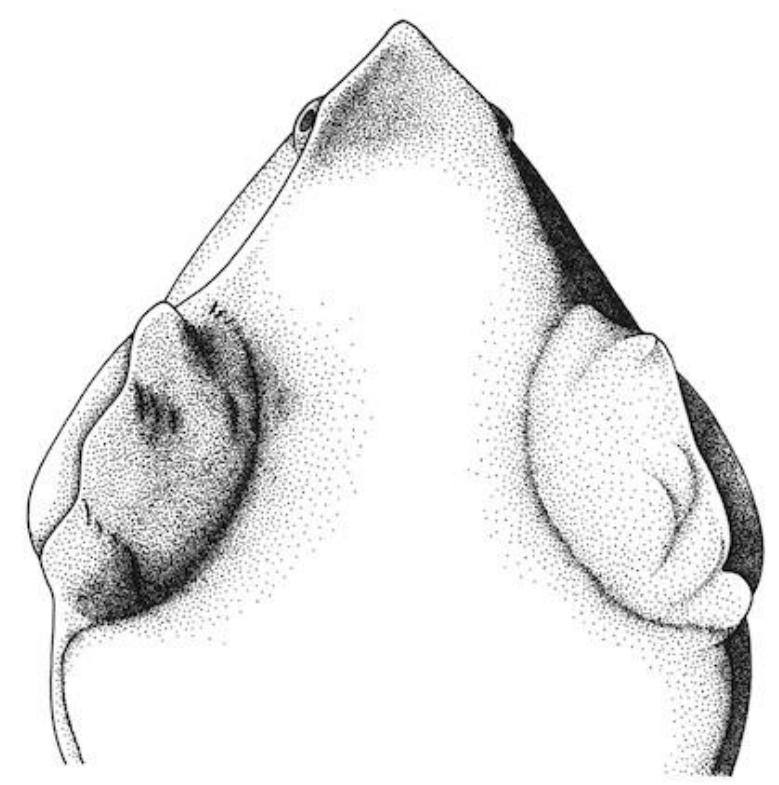

B

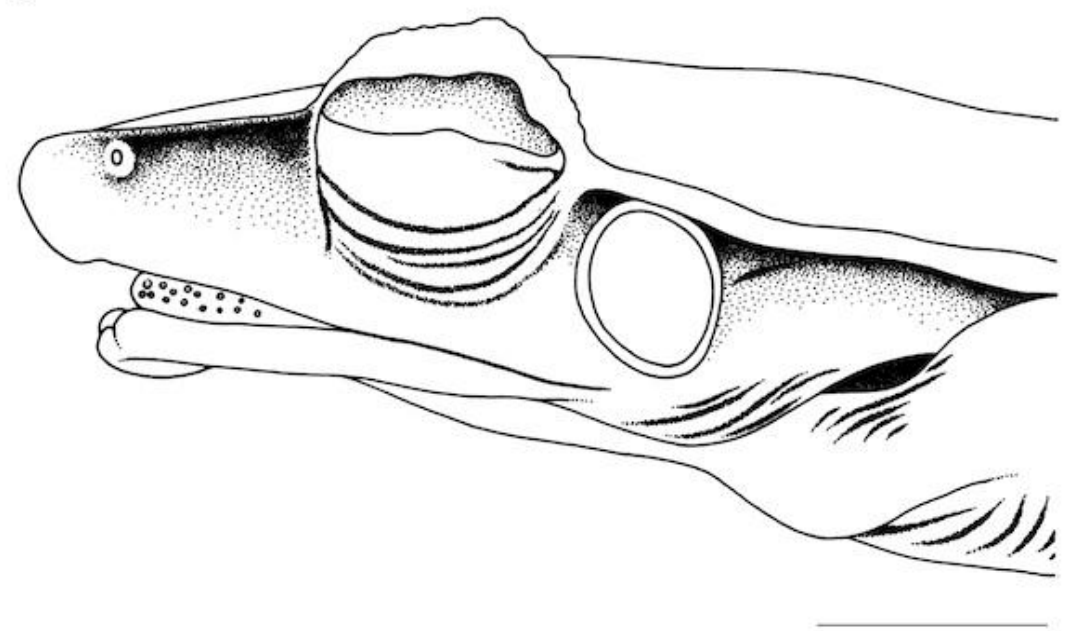

Figure 6. Head of Taruga eques, (A) dorsal and (B) lateral aspects, showing the pointed snout and the straight glandular fold extending from back of eye to mid-flank. (Scale bar, $5 \mathrm{~mm}$ ) 

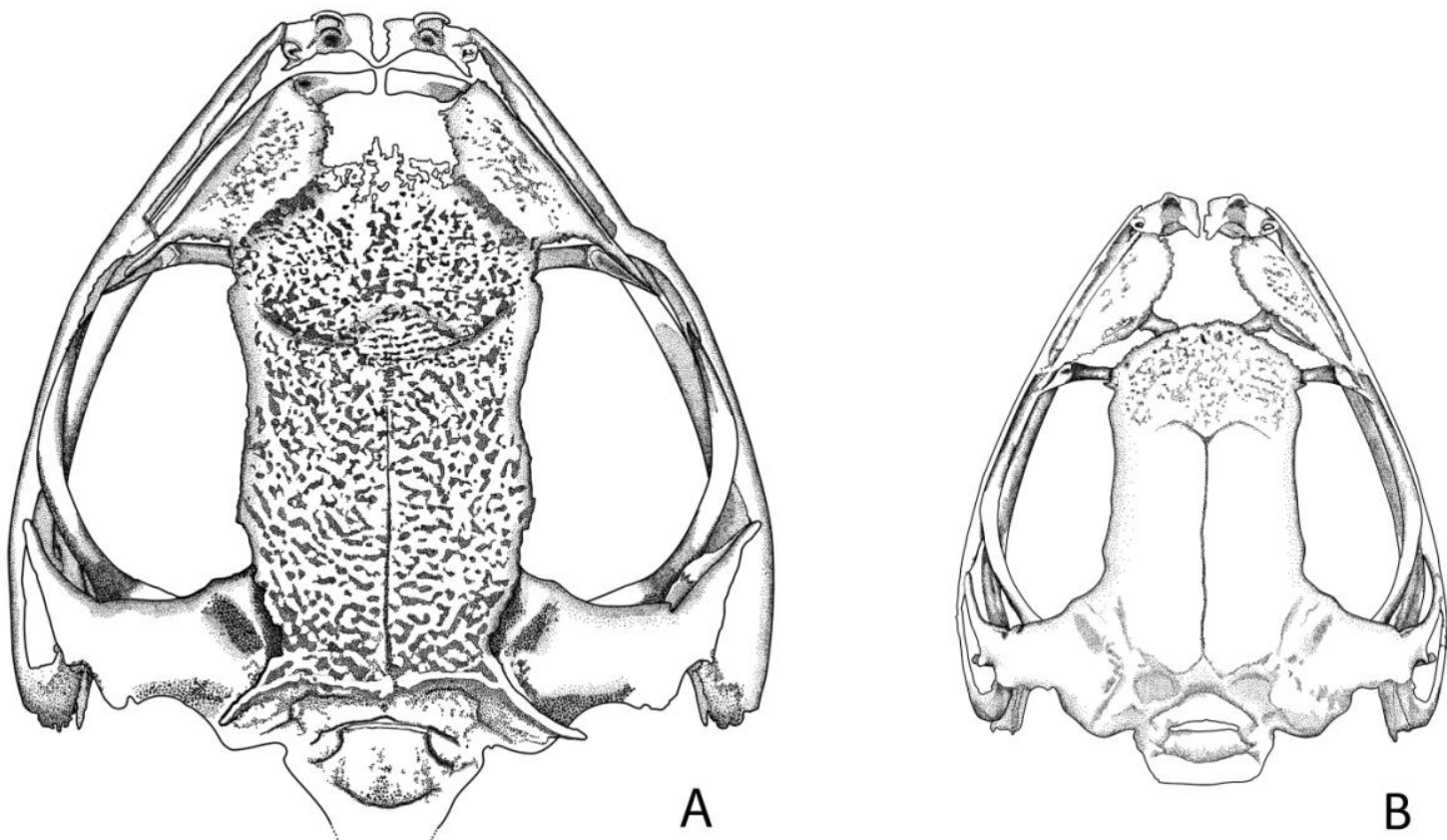

Figure 7. Dorsal aspect of the skull of (A) Polypedates cruciger (BMNH 1875.2.27.8; and (B) Taruga eques (BMNH 1947.2.27.56; drawings based on CT images. The two species differ from each other in the shape of the skull, frontoparietal and orbit; rugosity and shape of the anterior and posterior edges of the frontoparietal; and the shape of the pterygoid. (Scale bar, $5 \mathrm{~mm}$ )

Table 2. Differences in the external morphology of tadpoles of Polypedates cruciger and Taruga eques.

\begin{tabular}{|c|c|c|}
\hline $\begin{array}{l}\text { Tadpole external } \\
\text { morphology }\end{array}$ & Polypedates cruciger & Taruga eques \\
\hline \multicolumn{3}{|l|}{ Dorsal view } \\
\hline Snout shape & rounded & pointed \\
\hline Position of eyes & mostly lateral & mostly dorsal \\
\hline Tail end & with a whip-like flagellum & no whip-like flagellum on tail end \\
\hline Point of origin of tail & dorsal skinny lip and groove absent & dorsal skinny lip and groove present \\
\hline \multicolumn{3}{|l|}{ Lateral profile } \\
\hline Spiracle characteristics & $\begin{array}{l}\text { cylindrical, sinistral, centripetal; end } \\
\text { directed posteriorly }\end{array}$ & $\begin{array}{l}\text { sinistral, mostly attached to body; } \\
\text { inner wall free, aperture opens } \\
\text { laterally }\end{array}$ \\
\hline Origin of ventral tail fin & begins under body & begins at end of trunk \\
\hline Origin of dorsal tail fin & dorsal tail fin begins on the trunk & dorsal fin begins at the end of trunk \\
\hline Shape and position of vent & $\begin{array}{l}\text { between hind limb and tail; forms a } \\
\text { distinct conical tube with opening } \\
\text { at the end }\end{array}$ & $\begin{array}{l}\text { vent opens as an aperture, not } \\
\text { forming a tube; aperture dextral } \\
\text { between hind limb and tail }\end{array}$ \\
\hline
\end{tabular}




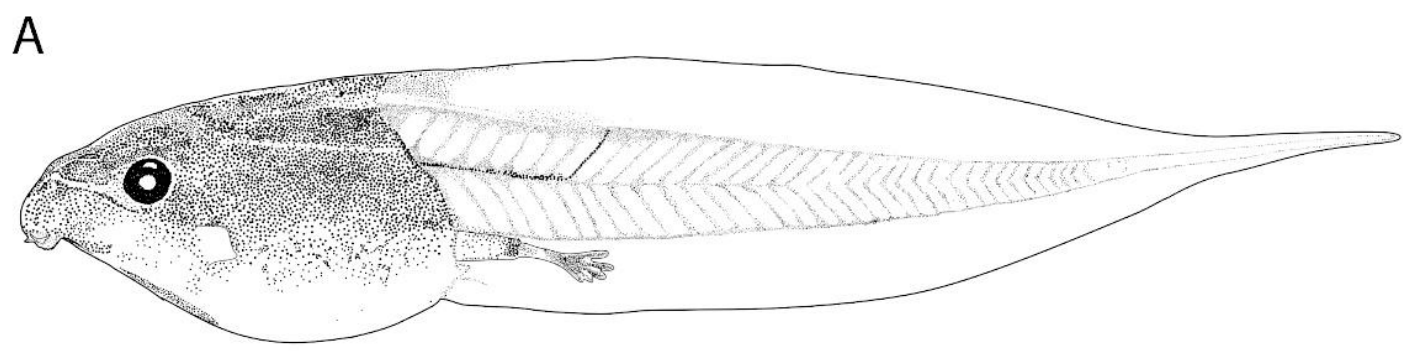

B

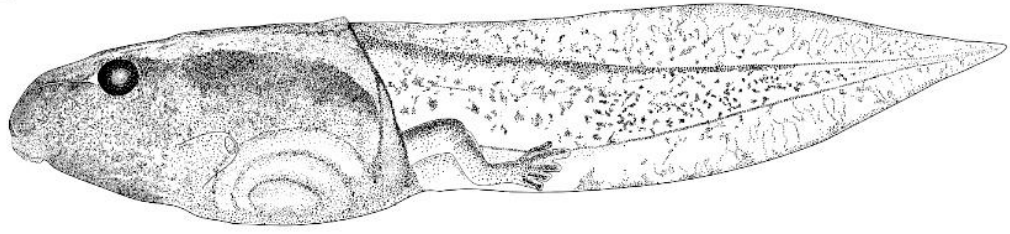

C

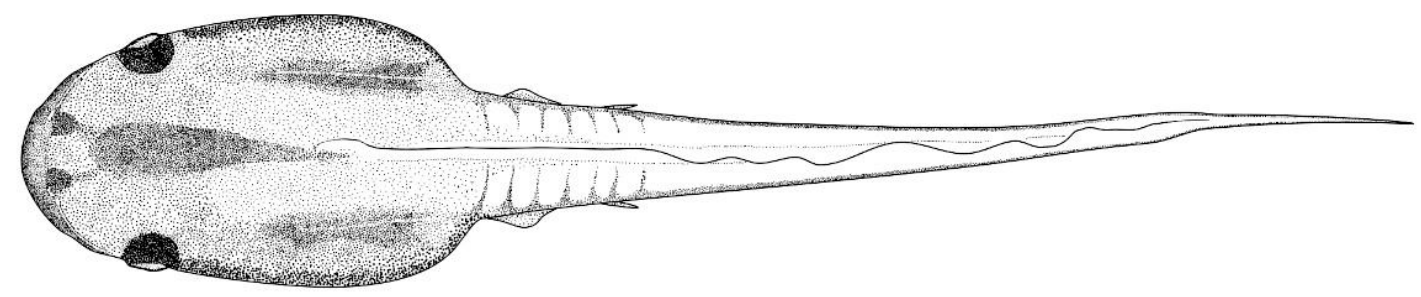

$\mathrm{D}$

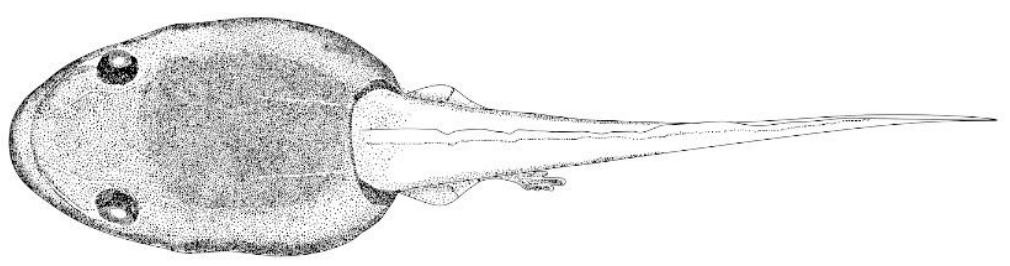

Figure 8. External features of Polypedates cruciger (A) left profile; (C) dorsal profile and Taruga eques (B) left profile; (D) dorsal profile. The two taxa differ in size and form, existence of tail-end flagellum, shape and form of the spiracle, and the point of origin of dorsal and ventral tail fin. (Scale bar $10 \mathrm{~mm}$ ) 

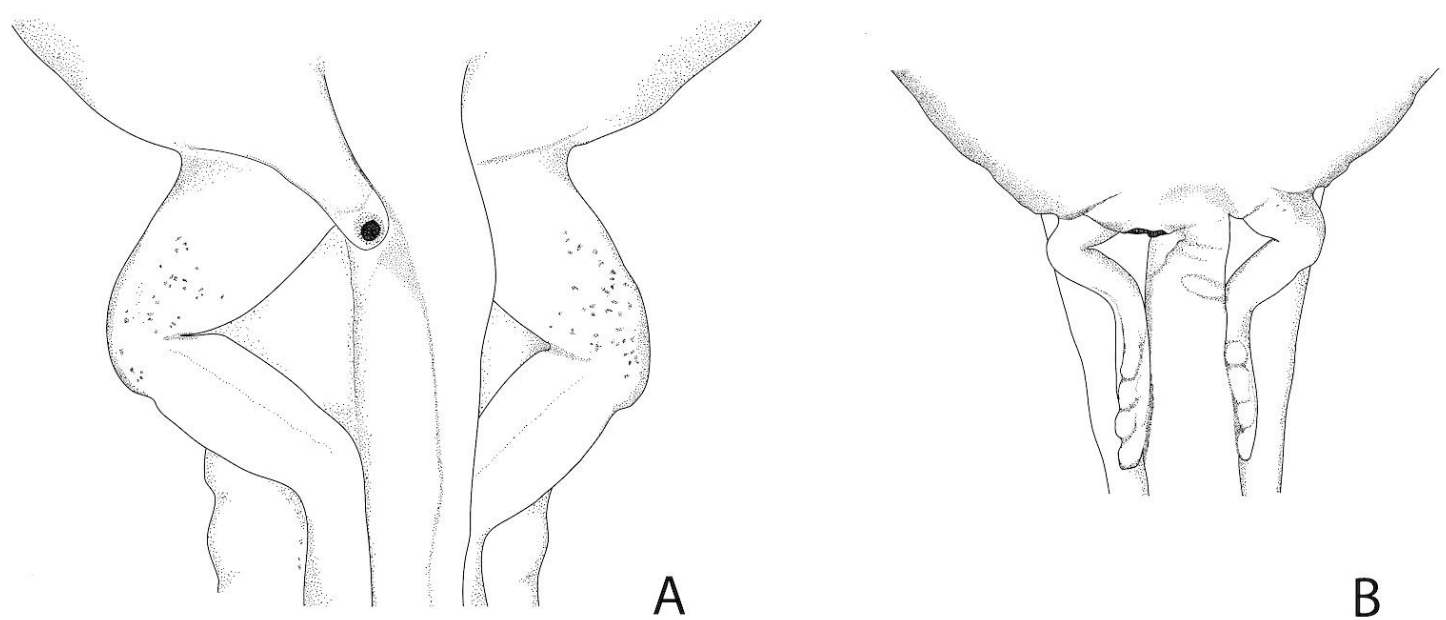

A

B

Figure 9. (A) Polypedates cruciger and (B) Taruga eques also differ in the form of the vent. While $P$. cruciger has a vent tube, T. eques has only a vent aperture. (Scale bar, $1 \mathrm{~mm}$ )

Table 3. Differences in buccal morphology between tadpoles of Polypedates cruciger and Taruga eques.

\section{Character}

Ventral buccal

Shape of prelingual arena

Prelingual arena papillae

Anterior prelingual arena palps

Posterior prelingual arena palps

Papillae on anterior wall of buccal cavity

Tongue shape

Lingual papillae

Tongue pigmentation

Tongue attachment

BFA

BFA pustulations

BFA papillae

Dorsal buccal

Prenarial arena

Anterior transverse ridge

Anterior projection on narial papillae

BRA papillae

Polypedates cruciger

Taruga eques

U-shaped (lunate)

one pair

two major digitations

long, with projections, medially directed

4-5 pairs

slightly conical

two unequally sized pairs

absent

fully attached to prominent buccal floor musculature, in a notch

triangular, elevated

more than 50

11-13

broad, U-shaped

crescentic

present

4 pairs heart-shaped (cardioid) absent (only a pair of pustulations) three major digitations flat and broad, multifurcated, posteriorly directed absent

rounded

a single pair

present

posteriorly attached, musculature indiscernible, notch absent

U-shaped, depressed

fewer than 50

19-21

broad, V-shaped

broad, V-shaped

absent

5 pairs 

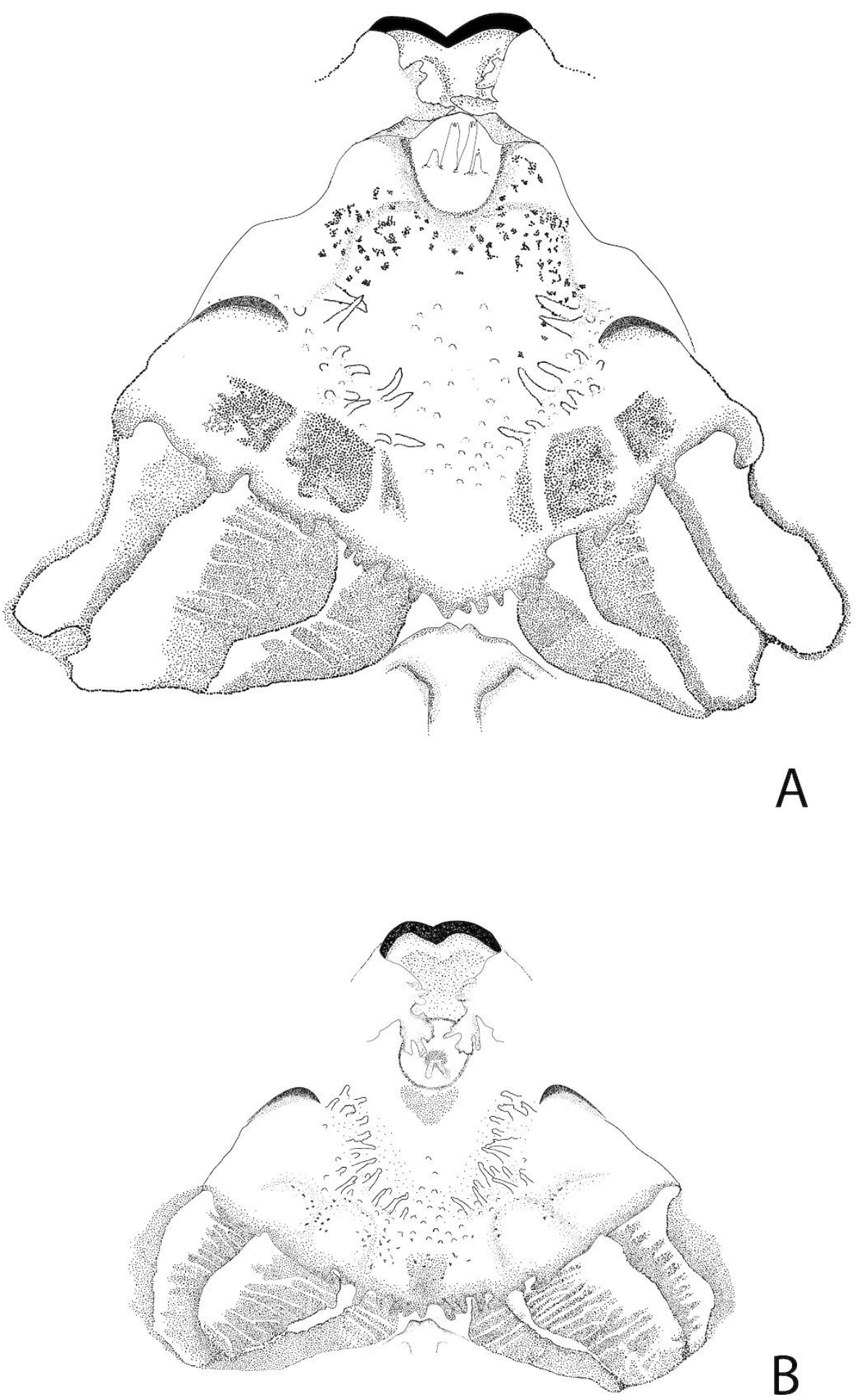

Figure 10. Ventral buccal region of (A) Polypedates cruciger and (B) Taruga eques. Presence of prelingual papillae and papillae of the anterior wall of buccal cavity, shape of tongue, attachment surface of tongue, features of the buccal floor arena, and number of buccal-floor arena papillae differ between the two taxa. (Scale bar, 1mm) 


\section{DISCUSSION}

Our phylogenetic results (Fig. 5) confirm those of several earlier less-well supported studies that identified Polypedates as the sister taxon of Rhacophorus. Liem (1970) and Wilkinson and Drewes (2000) recovered Rhacophorus and Polypedates as sister taxa, although Channing (1989) did not. Most previous mtDNA-based phylogenies failed to recover this sister-clade relationship (Richards and Moore, 1998; Meegaskumbura et al., 2002; Wilkinson et al., 2002), but intergeneric relationships are only weakly supported in those studies. The phylogeny of Frost et al. (2006), which is based on mtDNA and some nuclear DNA sequence data, recovers Chiromantis/Chirixalus as the sister taxon of Polypedates, and Rhacophorus as the sister taxon of a clade containing Chiromantis/Chirixalus + Polypedates.

There also is ambiguity in the morphological diagnoses of some species of Polypedates and Rhacophorus (Bossuyt and Dubois, 2001). Wilkinson et al. (2002), for example, show $P$. dennysi nested within Rhacophorus and allocate it to that genus (see Frost et al., 2006). By including in the present study the type species of Rhacophorus ( $R$. reinwardtii) and Polypedates (P. leucomystax) from Java, the type locality of each species, we seek to stabilize the identity of both genera.

A basal Sri Lankan clade can be distinguished within what was previously referred to as Polypedates. This endemic clade, for which we erect the new genus Taruga, is molecularly distinct (i.e., both well supported and deeply divergent) from remaining Polypedates species, including the two Sri Lankan species, P. maculatus and P. cruciger. As noted above, it also is differentiated morphologically from Polypedates. As presently understood the clade comprises three named species: T. fastigo, T. eques and T. longinausus However, our molecular results also suggest that Polypedates is more speciose than currently understood, as two $P$. cruciger species used in the current analysis are widely different from each other; we are currently in the process of describing this new form.

Based on examination of the species included in the present study, snout angles of Taruga and Polypedates do not overlap. However, this character may be sexually dimorphic, at least in some species (males tend to have more acutely-pointed snouts than females), hence we recommend that the sexes be compared separately when evaluating this character for taxonomic purposes.

Chiromantis occupies a well-supported basal position within the monophyletic foam-nesting group (Fig. 5). This arrangement agrees with the morphology-based phylogeny of Wilkinson and Drewes (2000), but not with those of either Liem (1970), who considered Chiromantis the sister group of Philautus, or Channing (1989), who considered Chiromantis as basal to all Rhacophoridae + Mantellidae, excluding Buergeria. Our result also differs from the mtDNA-based phylogenies of Richards and Moore (1998), Meegaskumbura et al. (2002) and Wilkinson et al. (2002), in which Chiromantis forms the sister group of Polypedates, although with only weak support. The present result also conflicts with the analysis of Richards et al. (2000), in which Chiromantis comprises a sister group of Rhacophorus, but again with only weak support. Our result reinforces the conclusions of Wilkinson et al. (2002) and Frost et al. (2006) that Chiromantis is nested within the Chirixalus clade, which, in our analysis, includes the type species of the genus, Chirixalus doriae (albeit from Laos the type locality is in Burma). We concur with Frost et al.'s (2006) recommendation that Chirixalus Boulenger, 1893, be regarded as a synonym of Chiromantis Peters, 1854.

Taruga is the sister group of the remaining species of Polypedates sensu stricto. The position of the Taruga + Polypedates clade as sister to Asian Rhacophorus and Chirixalus suggests an Asian origin of their common ancestor, with an ancient dispersal to Sri Lanka. Presence in Sri Lanka of Polypedates cruciger and $P$. maculatus indicates a second, more recent dispersal from mainland Asia to Sri Lanka. Since Taruga forms an isolated clade and is species depauperate, we regard it as a relict taxon. The biogeography of Taruga will be considered in a subsequent work.

Two genera of foam-nesting rhacophorid tree frogs are present in Sri Lanka: (1) Polypedates, with several species in Asia but just two in Sri Lanka $(P$. maculatus-widely distributed in South Asia; and P. cruciger-endemic to Sri Lanka, albeit widely distributed); and (2) Taruga, a Sri Lankan endemic, whose three constituent species (T. eques, T. fastigo and $T$. longinasus) each have restricted distributions mostly in the forested highlands. 
External morphology of tadpoles of $T$. longinasus was reported by Fernando and Dayawansa (1995) and Fig. 11. Their results agree with ours for $T$. eques in showing that $T$. longinasus lacks a tail-end flagellum, that the dorsal and anal fins seem to commence at the posterior end of body, and that the spiracle appears to have a similar form to the one we observe in T. eques. Additional studies on the morphology of both $T$. fastigo and T. longinasus, as well as species of the Polypedates and the Rhacophoridae are needed to confirm whether the derived characters and character states we observe in $T$. eques are synapomorphic in the genus.

All three species of Taruga show a restricted distribution within Sri Lanka, whereas Polypedates is widely distributed through South Asia. Taruga eques and T. fastigo are restricted to submontane and montane regions: T. eques occurs in the Central Hills and Knuckles Mountains; $T$. fastigo is restricted to the highest peaks of the Rakwana Hills (e.g., Morningside). Taruga longinasus is found in the mid-hill regions (of Rakwana Hills, and south and southwestern Central Hills) up to an elevation of about $600 \mathrm{~m}$, and in the lowland wet zone. Polypedates cruciger, on the other hand, is widely distributed in the lowlands of the southwestern "wet zone" (annual rainfall > $2500 \mathrm{~mm}$ ), extending to an elevation of about $1500 \mathrm{~m}$. It also occurs in the "intermediate zone" and the island's relatively dry south-eastern region, extending into the dry zone (annual rainfall < $2000 \mathrm{~mm}$ ). Polypedates maculatus is abundant in the dry zone lowlands and occurs also in the lowlands of the wet zone, especially along the coastal floodplain. It usually does not occur at elevations above $500 \mathrm{~m}$.

A
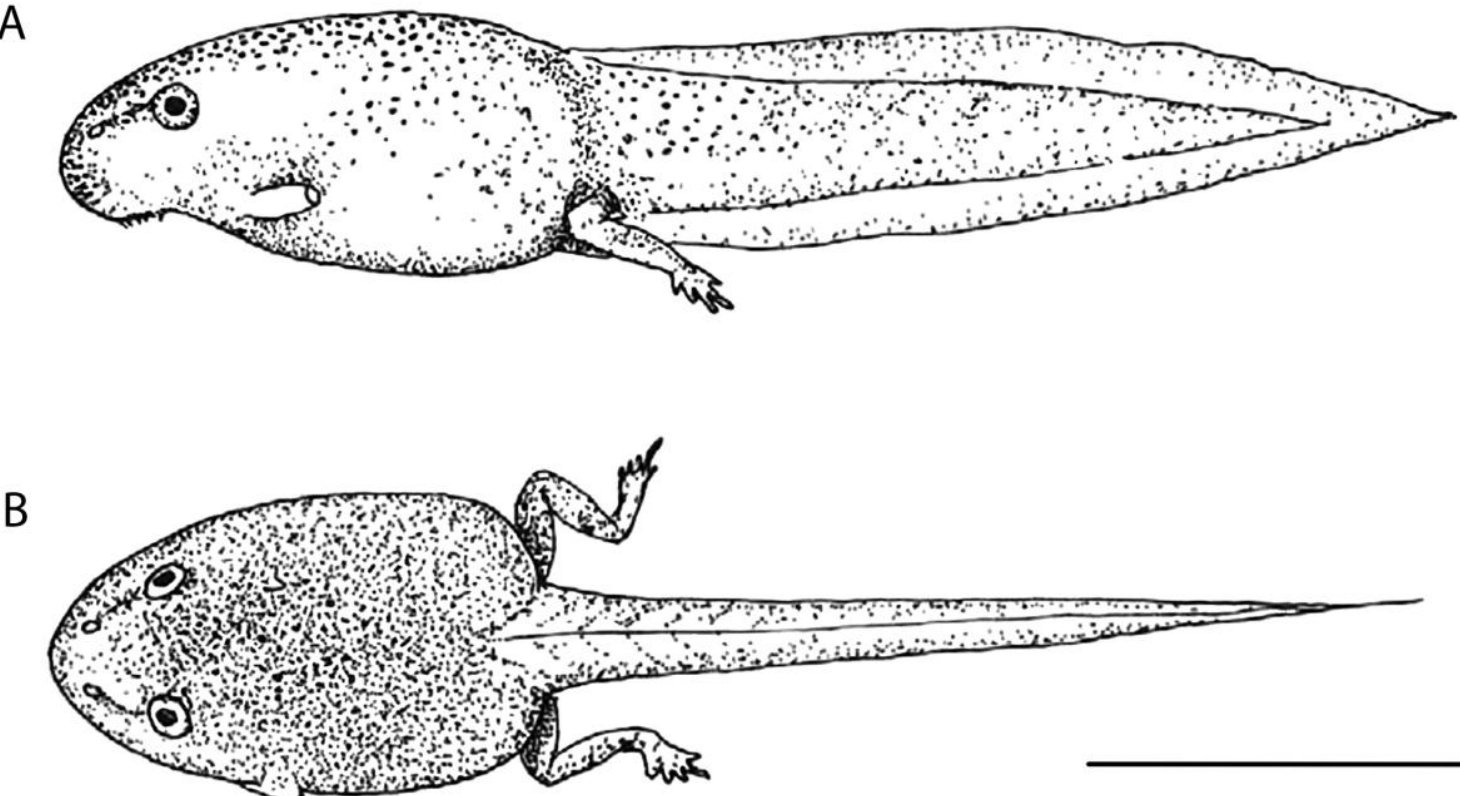

Figure 11. (A) Left profile and (B) dorsal profile of the tadpoles of $T$. longinasus, showing the absence of a flagellum. The body shape is similar to that of $T$. eques tadpoles. (Adapted from Fernando and Dayawansa, 1995). (Scale bar, $10 \mathrm{~mm}$ ) 
Table 4. Percent uncorrected pairwise genetic distances among foam-nesting genera of Rhacophoridae for the six gene fragments combined. Genetic distances to Taruga mostly overlap distances between the other pairs of foam-nesting genera.

$\%$ Uncorrected genetic distances

\begin{tabular}{lcccc}
\hline Genera & Taruga & Polypedates & Rhacophorus & Chiromantis \\
Taruga & $*$ & $22-28$ & $23-31$ & $24-31$ \\
Polypedates & - & $*$ & $25-30$ & $24-30$ \\
Rhacophorus & - & - & $*$ & $23-31$ \\
Chiromantis & - & - & - & $*$ \\
\hline
\end{tabular}

Bossuyt et al. (2004) presented evidence that the fauna of Sri Lanka and India show cladelevel endemism despite the multiple land-bridge connections between the island and the mainland during the past 50 million years, most recently up to about 10,000 years. Taruga appears to be another such a deeply divergent clade that Sri Lanka does not share with India.

Although genus-level genetic distances in Rhacophoridae have hitherto not been discussed comparatively, comparisons between pairs of other foam-nesting genera may be informative in validating Taruga as a distinctive genus. The uncorrected genetic distances (for all 6 gene fragments, both nuclear and mitochondrial, used in this study) between Chiromantis, Polypedates, Rhacophorus and Taruga varies in the range $22-31 \%$ (Table 4), that between Taruga and Polypedates being comparable to the divergences between the other genera.

\section{ACKNOWLEDGEMENTS}

We are grateful to Robert F. Inger and Harold Voris (Field Museum of Natural History, Chicago, USA); and Peter K. L. Ng and Kelvin Lim (Raffles Museum of Biodiversity Research, National University of Singapore) for the loan of tissue samples of the Southeast Asian taxa included in this study; and to Carla Cicero and Theodore Papenfuss (Museum of Vertebrate Zoology, University of Berkeley, California, USA), and The California Academy of Sciences, USA, for providing many other samples. José Rosado and the staff of the Herpetology Department, MCZ for their assistance in obtaining samples from various museums. We acknowledge the Forest Department and Department of Wildlife Conservation of Sri Lanka for collection and tissue-export permits. We are grateful to Prof. (Emeritus) Punchi
Banda Meegaskumbura for suggesting the Sanskrit/Sinhala name Taruga. We also thank Alexander Haas for granting permission to use his photographs of the tadpoles of $P$. otilophus and $P$. leucomystax, and Krishan Ariyasiri for the photograph of nest-making $P$. cruciger (Fig. 1). This work was supported by grants from the National Science Foundation (NSF) USA (DEB 0345885) to CJS and JH and the Society of Systematic Biologists (SSB) Graduate Student Award for Research (2002) to MM. Part of this work was facilitated through a Ziff Environmental postdoctoral fellowship to MM from Harvard University's Center for the Environment.

\section{REFERENCES}

Ahl, E. (1927). Zur Systematik der asiatischen Arten der Forschgattung Rhacophorus. Sitzungberichte der Geselschaft Naturforschender. Freunde zu Berlin, 1926: 3547.

Akaike, H. (1974). A new look at the statistical model identification. IEEE Transactions on Automatic Control, 19:716-723.

AmphibiaWeb (2011). AmphibiaWeb: information on amphibian biology and conservation, University of California, Berkeley, California: Available

http://www.amphibiaweb.org/

Bossuyt, F., Brown, R.M., Hillis, D.M., Cannatella, D.C. and Milinkovitch, M.C. (2006). Phylogeny and Biogeography of a Cosmopolitan Frog Radiation: Late Cretaceous Diversification Resulted in Continent-Scale Endemism in the Family Ranidae. Systematic Biology 55(4), 579594. 
Bossuyt, F. and Dubois, A. (2001). A review of the frog genus Philautus Gistel, 1848 (Amphibia, Anura, Ranidae, Rhacophorinae). Zeylanica 6:1-112.

Bossuyt, F., Meegaskumbura, M., Beenaerts, N., Gower, D. J., Pethiyagoda, R., Roelants, K., Mannaert, A., Wilkinson, M., Bahir, M. M., Manamendra-Arachchi, K., Ng, P. K. L., Schneider, C. J., Oommen, O. V. and Milinkovitch M. C. (2004). Local endemism within the western Ghats-Sri Lanka biodiversity hotspot. Science 306:479-481.

Bossuyt, F. and Milinkovitch, M. C. (2000). Convergent adaptive radiation in Madagascan and Asian ranid frogs reveal covariation between larval and adult traits. Proceedings of the National Academy of Sciences of the United States of America 97:6585-6590.

Channing, A. (1989). A re-evaluation of the phylogeny of Old World treefrogs. South African Journal of Zoology. 24:116-131.

Duellman W. E. and Trueb, L. (1986). Biology of Amphibians. McGraw-Hill, New York. Pp. 696.

Fernando, P. and Dayawansa, N. (1995). Description of the larval stages and notes on the reproduction of Polypedates longinasus (Ahl, 1927) (Amphibia, Rhacophoridae), Journal of South Asian Natural History 1(2): 235-240.

Frost, D. R., T. Grant, Faivovitch, J. N., Bain, R. H., Haas, A., Lio, C., Haddad, F. B., De Sa', R. A., Channing, A., Wilkinson, M., Donnellan, S. C., Raxworthy, C. J., Campbell, J. A., Blotto, B. A., Moler, P., Drewes, R. C., Nussbaum, R. A., Lynch, J. D., Green, D. M., Wheeler, W. C. (2006). The amphibian tree of life. Bulletin of the American Museum of Natural History 297:1370.

Gosner, K. L. (1960). A simplified table for staging anuran embryos and larvae with notes on identification. Herpetologica 16: 183-190.

Günther, A. C. L. G. (1858). Catalogue of the Batrachia Salientia in the collection of the British Museum, London. Trustees of the British Museum, London.

Hoegg, S., Vences, M., Brinkmann, H. and Meyer, A. (2004). Phylogeny and comparative substitution rates of frogs inferred from sequences of three nuclear genes. Molecular Biology and Evolution 21:1188-1200.

Huelsenbeck, J. P. and Ronquist, F. (2001). MRBAYES: Bayesian inference of phylogenetic trees. Bioinformatics 17:754-755.

Huelsenbeck, J. P., Ronquist, F., Neilsen, R. and Bollback, J. P. (2001). Bayesian inference of phylogeny and its impact on evolutionary biology. Science 294:2310-2314.

Liem, S. S. (1970). The morphology, systematics, and evolution of the Old World treefrogs (Rhacophoridae and Hyperoliidae). Fieldiana: Zoology 57:1-145.

Manamendra-Arachchi, K. and Pethiyagoda, R. (2005). The Sri Lankan shrub-frogs of the genus Philautus Gistel, $1848 \quad$ (Ranidae: Rhacophorinae), with description of 27 new species. The Raffles Bulletin of Zoology, Supplement 12:163-303.

Manamendra-Arachchi, M. and Pethiyagoda, R. (2001). Polypedates fastigo, a new tree frog (Ranidae: Rhacophorinae) from Sri Lanka. Journal of South Asian Natural History 5 (2): 191-199.

Mauro, S. D., Gower, D. J., Oommen, V. O., Wilkinson, M. and Zardoya, R. (2004). Phylogeny of caecilian amphibians (Gymnophiona) based on complete mitochondrial genomes and nuclear RAG1. Molecular Phylogenetics and Evolution 33:413427.

McDiarmid R. W. and Altig, R. (2000). Tadpoles: the biology of anuran larvae. The University of Chicago Press, Pp. 444.

Meegaskumbura, M. (2007). Molecular Systematics, Evolution, and Ecology of Sri Lankan shrub-frogs (Rhacophorinae: Pseudophilautus). Ph.D. Thesis. Department of Biology, Boston University, Massachussetts USA.

Meegaskumbura, M., Bossuyt, F., Pethiyagoda, R., Manamendra-Ararchchi, K., Bahir, M., Milinkovitch, M. C. and Schneider, C. J. (2002). Sri Lanka: an amphibian hotspot. Science 298: 379.

Murphy, W.J., Eizirik, E., O’Brien, S. J., Madsen, O., Scally, M., Douady, C. J., Teeling, E., Ryder, O. A., Stanhope, M. J., de Jong, W. 
W. and Springer, M. S. (2001). Resolution of the early placental mammal radiation using Bayesian phylogenetics. Science 294:23482351.

Palumbi, S. R. (1996). Nucleic acids II: The polymerase chain reaction. In: D. M. Hillis, C. Moritz, and B. K. Mable (Eds), Molecular Systematics, Sinauer Associates, Sunderland. Pp. 205-248

Posada, D. and Crandall, K. A. (1998). MODELTEST: testing the model of DNA substitution. Bioinformatics 14:817-818.

Rambaut, A. (1996). Se-Al: Sequence Alignment Editor. Available at http://www.evolve.zoo.ox.ac.uk/

Richards, C. M. and Moore, W. (1998). A molecular phylogeny of the Old World tree frog family Rhacophoridae. Journal of Herpetology 8:41-46.

Richards, C. M., Nussbaum, R. A. and Raxworthy, C. J. (2000). Phylogenetic relationships within the Madagascan boophids and mantellids as elucidated by mitochondrial ribosomal genes. African Journal of Herpetology 49: 1, 23-32.

Swofford, D. L. (2002). PAUP, phylogenetic analysis using parsimony (and other methods), v. 4b10. Sinauer Associates, Sunderland, MA.
Wassersug, R. J. (1976). Oral morphology of anuran larvae: terminology and general description. Occasional Papers of the Museum of Natural History, University of Kansas 1-23.

Wells, K. D. (2007). The ecology and behavior of amphibians. University of Chicago Press, Chicago. Pp. 1148.

Wilgenbusch J.C., Warren, D. L. and Swofford, D. L. (2004). AWTY: A system for graphical exploration of MCMC convergence in Bayesian phylogenetic inference. Available at http://www.ceb.csit.fsu.edu/awty

Wilkinson, J. A. and Drewes, R. C. (2000). Character assessment, genus level boundaries, and phylogenetic analysis of the family Rhacophoridae: A review and present day status. Contemporary Herpetology 2. Available at http://www.cnah.org/ch/ch/2000/2/

Wilkinson, J. A., Drewes, R. C. and Tatum, O. L. (2002). A molecular phylogenetic analysis of the family Rhacophoridae with an emphasis on the Asian and African genera. Molecular Phylogenetics and Evolution 24:265-273. 


\title{
APPENDIX 1
}

\begin{abstract}
Material Examined
Taruga fastigo. Holotype, male, 37.3 mm SVL, WHT 2352; Morningside Estate (near Rakwana), alt. 1060 m $\left(06^{\circ} 24^{\prime}\right.$ N, 80³8'E), coll. M.M. Bahir \& S.V. Nanayakkara, 14 I 1999. Paratypes (all from type locality.), females, 63.9 mm SVL, WHT 2027; 59.9 mm SVL, NMSL ARH14(a), coll. M.M. Bahir \& S.V. Nanayakkara, 05 VIII 1997. Females, 54.8 mm SVL, NMSL ARH14(b); 61.2 mm SVL, WHT 2343, coll. D. Gabadage \& M.M. Bahir, 05 IX 1996. Males, 36.0 mm SVL, WHT 2335; 39.5 mm SVL, WHT 2340; 36.0 mm SVL, WHT 2341; 36.4 mm SVL, WHT 2347; 35.3 mm SVL, WHT 2348; $39.1 \mathrm{~mm}$ SVL, WHT 2349, coll. M.M. Bahir \& S.V. Nanayakkara, 12 I 1999. Tadpoles, WHT 2902, SVL 17.0 mm, stage 44; WHT 2903, SVL 17.9, stage 43; WHT 2904, SVL 16.9, stage 43; WHT 2905, $17.0 \mathrm{~mm}$ SVL, stage 43; coll. M.-Arachchi \& S.V. Nanayakkara, 30 VI 2000.
\end{abstract}

Taruga eques. Syntypes (6 ex.). All males, $39.1 \mathrm{~mm}$ SVL, BMNH 1947.2.27.54; $36.9 \mathrm{~mm}$ SVL, BMNH 1947.2.27.55; 36.7 mm SVL, BMNH 1947.2.27.56; 36.6 mm SVL, BMNH 1947.2.27.57; 36.0 mm SVL, BMNH 1947.2.27.58; 35.1 mm SVL, BMNH 1947.2.27.59, Ceylon; H. Cuming. Female, 71.0 mm SVL, WHT 968, Horton Plains, alt. $2135 \mathrm{~m}\left(06^{\circ} 46^{`} \mathrm{~N}, 80^{\circ} 47^{\prime} \mathrm{E}\right)$, coll. D. Gabadage \& J. Karunaratne, 04 III 1995. Two ex. males, $32.7 \mathrm{~mm} \mathrm{SVL;} 33.8 \mathrm{~mm}$ SVL, WHT 1238, Haputale, alt. $1525 \mathrm{~m}\left(06^{\circ} 46^{\prime} \mathrm{N}\right.$, 8052’E), coll. D. Gabadage, 01 V 1996. Female, $59.2 \mathrm{~mm}$ SVL, WHT 1313, Pattipola, alt. $1890 \mathrm{~m}$ (0651'N, 8050’E), coll. D. Gabadage, 24 VI 1996. Two ex, males, $36.0 \mathrm{~mm}$ SVL; $37.5 \mathrm{~mm}$ SVL, WHT 1707, Hakgala (near Nuwara Eliya), alt. 1830 m (06 $55^{\prime}$ N, 8049’E), coll. M.M. Bahir \& D. Gabadage, 11 VI 1996. Female, $61.4 \mathrm{~mm}$ SVL, WHT 2316, Agra Arboretum, Agarapatana, alt. $1555 \mathrm{~m}\left(06^{\circ} 51^{\prime} \mathrm{N}\right.$, 8041'E), coll. M.M. Bahir \& S.V. Nanayakkara, 05 X 1998. Nine ex., 33.1-38.3 mm SVL, NMSL ARH 3 (a), Lindula, alt. $1265 \mathrm{~m}\left(06^{\circ} 55^{\prime} \mathrm{N}, 80^{\circ} 41^{\prime} \mathrm{E}\right)$. Male, $42.5 \mathrm{~mm}$ SVL, WHT 2937, Moray Est., Maskeliya, alt. $1370 \mathrm{~m}\left(06^{\circ} 48^{\prime} \mathrm{N}, 80^{\circ} 31^{\prime} \mathrm{E}\right)$, coll. K. Manamendra-Arachchi, $04 \mathrm{~V} 2000$.

Taruga longinasus. Holotype (holotype of Ixalus nasutus Günther, 1868), female, $58.5 \mathrm{~mm}$ SVL, BMNH 1947.2.8.61, Southern Ceylon; coll. Higgins. Female, 55.2 mm SVL, WHT 778, Parawalatenna (Kitulgala), alt. $150 \mathrm{~m}\left(06^{\circ} 59^{\prime} \mathrm{N}, 8^{\circ} 24^{\prime} \mathrm{E}\right)$, coll. M.M. Bahir \& D. Gabadage, 21 XII 1995. Two ex. male, $44.0 \mathrm{~mm}$ SVL; female, $58.6 \mathrm{~mm}$ SVL, WHT 1176, Koskulana (near Panapola), alt. $460 \mathrm{~m}\left(06^{\circ} 25^{\top} \mathrm{N}\right.$, $80^{\circ} 27^{\prime}$ E), coll. M.M. Bahir \& D. Gabadage, 23 V 1996. Female, 57.7 mm SVL, WHT 1743, Kudawa (near Weddagala), alt. $460 \mathrm{~m}\left(06^{\circ} 26^{\prime} \mathrm{N}, 80^{\circ} 25^{\prime} \mathrm{E}\right)$, coll. M. Wijesinghe, 04 VIII 1997. Four ex., males, $43.2 \mathrm{~mm}$ SVL, WHT 2304; 45.8 mm SVL, WHT 2305; 42.0 mm SVL, WHT 2306; 40.5 mm SVL, WHT 2307; Kanneliya (near Galle), alt. $150 \mathrm{~m}\left(06^{\circ} 15^{\prime} \mathrm{N}, 80^{\circ} 20^{\prime} \mathrm{E}\right)$, colll. M.M. Bahir, M.M. Bopage \& S. Udayanga, 20 X 1998. Male, $45.5 \mathrm{~mm}$ SVL, WHT 2353, Kanneliya (near Galle), alt. $150 \mathrm{~m}\left(06^{\circ} 15^{\prime} \mathrm{N}, 80^{\circ} 20^{\prime} \mathrm{E}\right)$, coll. S. Batuwita \& M.M. Bopage, 13 VII 1998.

Polypedates maculatus. Female, 38.6 mm SVL, WHT 965 Mahiyanganaya, alt. $90 \mathrm{~m}\left(07^{\circ} 19^{`} \mathrm{~N}, 80^{\circ} 59^{\prime} \mathrm{E}\right)$,

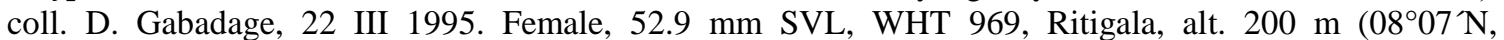
$\left.80^{\circ} 40^{\prime} \mathrm{E}\right)$, coll. D. Gabadage \& S. Dharmasiri, 06 X 1994. Female, $58.3 \mathrm{~mm}$ SVL, WHT 973, Piliyandala, alt. $12 \mathrm{~m}\left(06^{\circ} 48^{\prime} \mathrm{N}, 7^{\circ} 55^{\prime} \mathrm{E}\right)$, colle. S. Dharmasiri, 06 XII 1994. Male, $42.3 \mathrm{~mm}$ SVL, WHT 974, Palatupana (Kirinda), alt. $3 \mathrm{~m}\left(06^{\circ} 16^{\prime} \mathrm{N}, 81^{\circ} 24^{\prime} \mathrm{E}\right)$, coll. R. Pethiyagoda, 1994. Female, $38.6 \mathrm{~mm}$ SVL, WHT 1098, Kottawa (Galle), alt. 60 m $\left(06^{\circ} 06^{\prime} \mathrm{N}, 80^{\circ} 20^{\prime} \mathrm{E}\right)$, coll. M.M. Bahir, 07 V 1995. Female, 46.6 mm SVL, WHT 1301, Polonnaruwa, alt. $55 \mathrm{~m}\left(07^{\circ} 56^{\prime} \mathrm{N}, 81^{\circ} 00^{\prime} \mathrm{E}\right)$, coll. D. Gabadage \& M.M. Bahir, $02 \mathrm{I}$ 1996. Female, 62.7 mm SVL, WHT 2350, Yakkala, alt. $30 \mathrm{~m}\left(07^{\circ} 05^{\prime} \mathrm{N}, 80^{\circ} 02^{\prime} \mathrm{E}\right)$, coll. M.M. Bahir, 1999. Female, $42.53 \mathrm{~mm}$ SVL, WHT 1086, Modera (Colombo), alt. $4 \mathrm{~m}\left(06^{\circ} 58^{\prime} \mathrm{N}, 7^{\circ} 52^{\prime} \mathrm{E}\right)$, coll. M.M. Bahir, 28 IX 1995.

Polypedates cruciger. Syntypes (4 ex.), male, $53.5 \mathrm{~mm}$ SVL, ZSI A 10178; female, $78.1 \mathrm{~mm}$ SVL, ZSI A 10179; female, 78.9 mm SVL, ZSI A 10177; female, $80.1 \mathrm{~mm}$ SVL, ZSI A 10176, Ceylon; E.F. Kelaart. Male, $59.8 \mathrm{~mm}$ SVL, WHT 202, Lihinigala- Yattapatha (Moragala near Agalawatta), alt. $150 \mathrm{~m}\left(06^{\circ} 23^{\prime} \mathrm{N}\right.$, $80^{\circ} 17^{\prime}$ E), coll. K.M.-Arachchi, 24 XI 1993. Female, $73.1 \mathrm{~mm}$ SVL, WHT 1090, Monaragala, alt. $150 \mathrm{~m}$ $\left(06^{\circ} 52^{\prime} \mathrm{N}, 8^{\circ} 20^{\prime} \mathrm{E}\right)$, coll. K.M.-Arachchi \& D. Gabadage, 17 X 1994. Female, $81.0 \mathrm{~mm}$ SVL, WHT 1092, Navinna (Galle), alt. $15 \mathrm{~m}\left(06^{\circ} 04^{\prime} \mathrm{N}, 80^{\circ} 12^{\prime} \mathrm{E}\right)$, coll. M.M. Bahir \& M.M. Bopage, 6 IX 1995. Female, $75.6 \mathrm{~mm}$ SVL, WHT 1093, Galge (between Kataragama and Buttala), alt. $90 \mathrm{~m}\left(06^{\circ} 33^{\prime} \mathrm{N}, 81^{\circ} 19^{\prime} \mathrm{E}\right)$, coll.M.M. Bahir, May 1995. Male, $54.3 \mathrm{~mm}$ SVL, WHT 2351, Ambalangoda, alt. $15 \mathrm{~m}\left(06^{\circ} 14^{`} \mathrm{~N}\right.$, $80^{\circ} 03^{\prime}$ E), coll. A.I. Alagiyawadu, 1999.

Polypedates biscutiger. Holotype, male, 55.2 mm SVL, ZMB 3049; from Ceylon. 